\title{
CEMENT AND CONCRETE MATERIALS.
}

\section{CONCRETE MATERIALS PRODUCED IN THE CHICAGO DISTRIC'I.}

By Ernest F. Burchard:

INTRODUCTION.

In connection with laboratory studies of the structural materials of the United States at the structural-materials laboratories of the United States Geological Survey in St. Louis, the writer spent several weeks in Chicago and vicinity, in the summer of 1906, obtaining representative samples of concrete materials. The location, extent, and geologic relations of the deposits sampled were noted, so as to supplement the experimental data obtained, and a general familiarity with the processes of preparation of material was gained. When the more important laboratory work on the concrete materials of this district shall have been completed a separate bulletin on the subject will probably be published. The present paper consists mainly of abstracts from the text of the proposed bulletin.

The term Chicago district as used in this paper is applied to the area in northeastern Illinois and southeastern Wisconsin in which concrete materials are produced principally for the Chicago market. The main portion of the district is bounded rather definitely on the east by the Illinois-Indiana State line; on the south by an east-west line passing about 7 miles south of Joliet; on the west by the west line of Kane and Kendall counties, and on the north by an east-west line passing just north of Lake Geneva, Wis. The area thus embraced is a quadrilateral 80 miles from north to south and 55 miles from east to west. About 500 square miles of this quadrilateral lies in Lake Michigan, so that there remains as land area about 3,900 square miles. (See fig. 24.) Concrete materials used principally in the Chicago market are pro- 


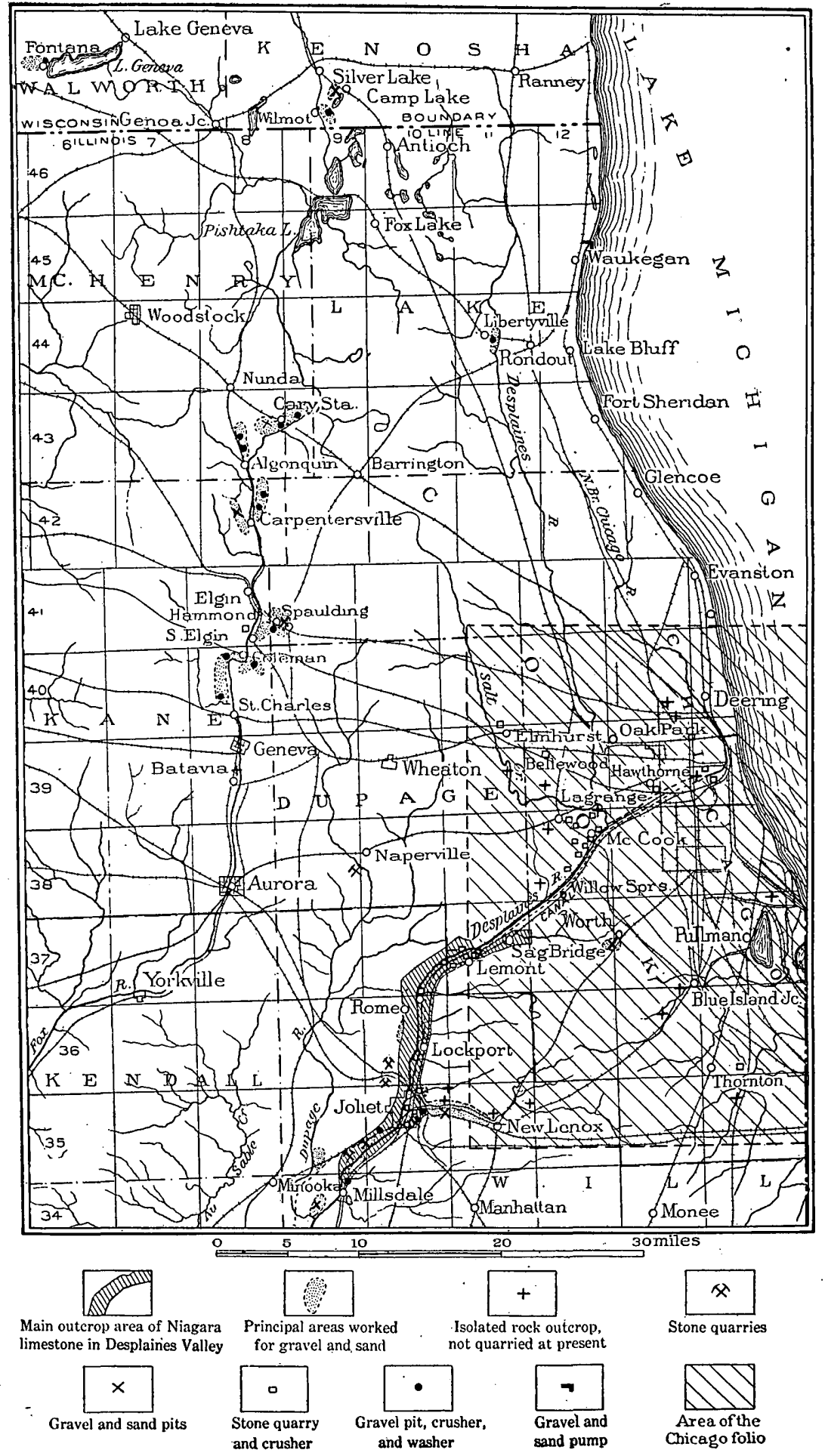

FIG. 24.-Map of main portion of district from which Chicago derives concrete materials. 
duced also at three places beyond the area thus outlined, viz, Kankakee, Ill., and Beloit and Janesville, Wis. In a city having more than $2,000,000$ inhabitants it is to be expected. that a great deal of structural material such as dimension stone, granite blocks, clay for bricks, tile, and terra cotta, as well as limestone, sand, and gravel for concrete purposes should be brought from considerable distances. The significant fact has been brought out, however, during a brief study of the field, that Chicago and her environs, included within the area described above, produce practically all the concrete material that is used locally, besides nearly all the ordinary dimension stone and common clays. The granite, marbles, and finer grades of dimension stones, flagging, curbing, and fire clays are brought from various outside States. The granite areas near Green Lake, Wis., the limestone area near Bedford, Ind., the sandstone area near Berea, Ohio, and the clay mines of Illinois, Indiana, and Ohio, are all important contributors to Chicago construction work.

The importance to Chicago of a near-by and adequate supply of raw materials for concrete purposes is very great, especially as concrete construction in its various forms is at present making more rapid advances than any other type of such work.

\section{CONSTIT́UUEN'T MATERIATS.}

VARIETIES.

The concrete materials produced in the Chicago district consist, in the order of quantities produced, of crushed magnesian limestone; sand; gravel, part of which is crushed; and Portland and natural cements. The crushed stone constituent closely approximates dolomite in composition, and is derived from the Niagara formation, which underlies the entire district, either outcropping at the surface or lying below thicknesses of glacial drift ranging from a few feet to 125 feet. The sand and gravel are derived from three types of material- $(a)$ glacial drift and outwash from the drift sheet, $(b)$ shore deposits of the present Lake Michigan, and $(c)$ deposits on old beaches of the former extended glacial lake. Cements, though manufactured at Chicago, are not strictly of local materials, the limestone that enters into their composition being brought from. Fairmount, a point in east-central Illinois about 100 miles south of the district as defined in this paper.

VALUE.

It has proved difficult to ascertain exactly the value of the various materials produced in the Chicago district that are used in concrete work, for the reason that in making returns producers are not always able to state definitely the uses to which the whole of their output-of broken stone is put. However, if we consider as concrete material 
all the crushed stone produced, except that sold for flux and for lime burning, the approximate value of this material produced in the district in 1906 was nearly $\$ 2,000,000$. The value of the sand produced during the same period was $\$ 205,500$, and that of the gravel was $\$ 198,034$. The total value of these concrete materials was therefore a little less than $\$ 2,500,000$. Returns for 1907 are not yet available, but it is likely that the figures for that year will not exceed those of 1906, as general building operations were greatly curtailed during 1907. The extensive construction work at the new town of Gary, Ind., being built by the United States Steel Corporation, probably offset in part at least the general inactivity in Chicago, the stone for Gary being almost wholly derived from the Chicago district.

\section{DETAILED DESCRIPTION OF MATERIALS.}

NIAGARA LIMESTONE.

\section{CHARACTER AND DISTRIBUTION.}

The Niagara limestone of the Silurian system underlies all but the southwest corner of the district. It consists mainly of highly magnesian limestone, but contains some shale near the base. Under probably nine-tenths of the area the rock is covered by glacial drift and recent soil and alluvium, the total thickness of which, in places, is as great as 125 feet, although generally it ranges between 30 and 80 feet. The exposures of Niagara rock are mostly in the southeastern quarter of the district as defined in this paper, and they are due (a) to irregularities in the bed-rock surface, $(b)$ to stream erosion, or $\left(^{c}\right)$ to a combination of these two causes. The preglacial surface or bedrock topography was undulating as compared with the present flat plain upon which Chicago stands, and the ancient hills of limestone are consoquently buried by a less thickness of drift than the valleysin fact, in several places these limestone hills reach the present surface.

Within the city limits of Chicago there are 10 or more places where the limestone either is exposed in a small area or else has been found to be so thinly covered by drift that stripping and quarrying are practicable. West, southwest, and south of the city there are 25 or more small, isolated exposures, at most of which quarrying is now or has been carried on.

The main outcrop area in the district extends along the valley of Desplaines River from Sag Bridge to a point 10 miles below Joliet. Here the rock forms the valley floor, overlain in places by a few feet of alluvium or by outwash sand and gravel, and locally it rises 30 to 50 feet in the bluffs. A few exposures occur also along other streams within the district, such as Salt Creek near Lagrange, Dupage River near Naperville, and Fox River at Batavia, St. Charles, and South Elgin. (See map, fig. 24.) 
The total thickness of the Niagara formation in the district ranges from 250 to more than 400 feet, and it is probable that the original thickness was greater than this, because there was opportunity for preglacial erosion of beds lying above. the present surface.

The character of the rock at the various outcrops and quarries within the area covered by the Chicago geologic folio is described in that folio by William C. Alden. ${ }^{a}$ Since the folio was published important new quarries have been opened within that area, particularly at Gary, Lagrange, and McCook.

Just southeast of Lagrange, on the northeast side of the Chicago Junction Railway, are the quarries of the Federal Stone Company and the Lagrange Stone Company, both of which have been opened within the last two or three years, and are about 20 feet deep. The strata do not outcrop at this place, although they approach within a foot or two of the surface, where the cover is thinnest. The surface of the rock is uneven, and a short distance to the east and northeast the cover becomes too thick for stripping. The rock has generally a slight dip to the southeast, but in places dips as steep as $20^{\circ}$ were noted. The top rock is rather thin bedded, and generally is oxidized to a buff color 2 to 10 feet below the surface, but is fairly white below the oxidized zone. The composition of the rock is shown by analyses 4 and 5 on page 394 .

A new quarry was being opened near McCook in the summer of 1907 by the United States Crushed Stone Company. 'The stripping is thin and when removed discloses beds that are much fractured and weathered to a light-buff color the full depth of the opening, about 1.5 feet. Work is being pushed at this quarry, the excavation being facilitated by use of a steam shovel. Clay pockets are encountered in places in the limestone. The product is crushed and sold at present mainly for fluxing material." The average analysis (No. 7, p. 394) indicates the composition of the rock, and illustrates the fact that, although the material may be uniformly of a buff color, rather than white, it is quite as free from impurities as the unoxidized beds found at greater depths.

From the analysis which was submitted by the stone producers the rock is seen to be a fairly pure magnesian limestone, closely approximating the composition of dolomite, and therefore highly desirable for fluxing purposes. On account of its buff color its value should not be less for concrete material, except where a very light-colored stone is required for exposed construction. After the quarry reaches greater depth the lighter colored stone will be found.

a Description of the Chicago district: Geologic Atlas U. S., folio 81, U. S. Geol: Survey, 1902. 
At Gary, southwest of McCook, is the new quarry of Dolese \& Shepard. In August, 1907, this opening comprised about 15 acres and showed a section about as follows:

Section of Niagara limestone at Dolese \& Shepard quarry, Gary, Ill.

Soil and drift............................ 6 inches to 4 feet.

Magnesian limestone, buff colored, slightly stained and weathered into thin strata. .................. 4 to 10 feet.

Magnesian limestone, light grayish blue, ranging from fine grained and dense to fairly porous; the beds are thicker than the surface rock, reaching a thickness in places of 15 inches; a few clay seams are present where the bedding. planes are irregular and in joint planes; fossils are abundant..........................................

The rock lies almost horizontal, and is cut by two sets of joints nearly at right angles to each other and extending northeast-southwest and northwest-southeast. In the section are three or four bands of light pinkish-gray porous rock, 7 to 12 inches thick, that can be traced halfway round the opening or farther, and such rock is found to make the most excellent lime. Crushed stone, rubble, and flux are the principal products here, and lime is soon to be burned.

The composition of the rock at Gary is shown by analysis No. 8, page 394, which represents an average of twenty-seven analyses, one being made each week throughout the last half of 1903, a total of 811 carloads having been sampled.

The following section represents a quarry at Lemont:

\begin{tabular}{|c|c|c|}
\hline & 1 & 6 \\
\hline Magnesian limestone, thin bedded, cherty............. & 4 & \\
\hline 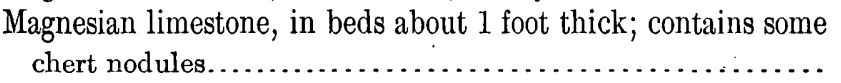 & 3 & \\
\hline $\begin{array}{l}\text { Magnesian limestone, similar to above, but in beds } 10 \text { inches } \\
\text { thick }\end{array}$ & 1 & 8 \\
\hline $\begin{array}{l}\text { Magnesian limestone, massive, very cherty, in two beds of equal } \\
\text { thickness } \ldots \ldots \ldots \ldots \ldots \ldots \ldots \\
\end{array}$ & 2 & 5 \\
\hline Magnesian limestone, sparingly cherty $\ldots \ldots \ldots \ldots \ldots \ldots \ldots \ldots$ & 1 & 9 \\
\hline 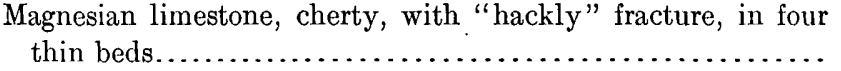 & 1 & 3 \\
\hline Magnesian limestone, gray, fine grained, chert free, massive bed. & 2 & 5 \\
\hline 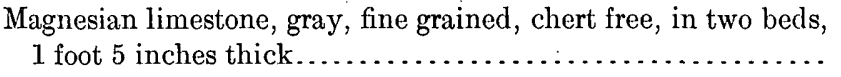 & 2 & 10 \\
\hline 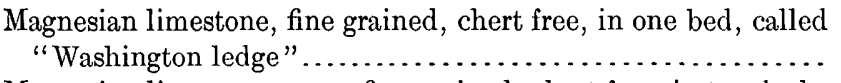 & 1 & 3 \\
\hline 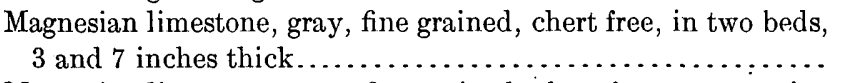 & & 10 \\
\hline $\begin{array}{l}\text { Magnesian limestone, gray, fine grained, chert free, one massive } \\
\text { bed } \ldots \ldots \ldots \ldots \ldots\end{array}$ & & $3-11$ \\
\hline
\end{tabular}

The cherty beds at this quarry can not be used for dimension stone, but they make good road material and ballast. 
On the north side of Desplaines Valley, about three-fourths of a mile northeast of Lemont, the Niagara limestone rises 35 to 50 feet in the bluff at the quarry of the Young Stone Company. Here the following section is exposed:

Generalized section at quarry of Young Stone Company, Lemont.

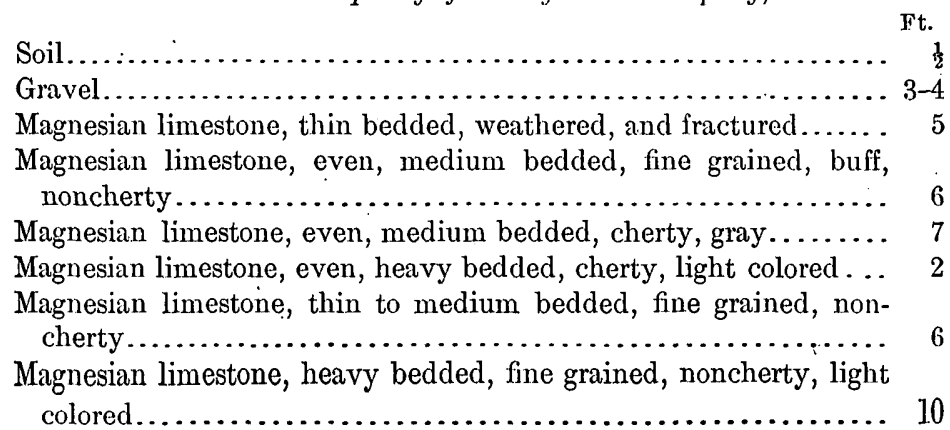

Rubble, dimension, and crushed stone are quarried from these beds.

Down the river from Lemont to a point about 10 miles below Joliet, the Desplaines Valley is cut in the rock so that exposures are numerous, both along the valley sides and in quarries, excavated in the valley bottom. The sanitary and ship canal of Chicago, extending nearly to Joliet, has been cut in the rock along this part of its course and consequently a large quantity of broken rock is available here. This material is being gradually utilized for riprap, ballast, filling, and crushed stone. At Lemont broken stone from the spoil banks of the canal is being loaded on barges and carried to Chicago, where it is used in lake front improvement work at Lincoln Park. Two miles below Lemont the Western Stone Company operates two crushers which are converting the rock of the spoil bank into concrete material, and the product is shipped to Chicago via the canal. 'The weathering of the rock where it has been piled for ten years has not been great. The material is mainly hard and gritty, but the surface rock is, of course, oxidized on the outside. Some portions of the spoil bank naturally furnish rock that is preferable to that in other localities, depending on the texture and the amount of chert and of clay present.

For about 3 miles below Lemont the valley sides are lined with abandoned quarries, where excellent dimension stone was obtained in the days before concrete construction was extensively employed. The rock suitable for dimension stone, known to the trade as "Athens marble," is found in its best development at and near Lemont, although good beds of it are found as far south as Joliet. Quarrymen have applied the term "tame stone" to rock that is fine grained, smooth textured, even bedded, and noncherty, and such rock makes the best dimension stone. They have likewise applied the term "wild rock" to rock that is irregularly bedded, breaks with a rough fracture, and contains argillaceous material or chert or both. Such 
rock often makes very desirable crushed stone, and although it had to be discarded before the era of concrete, it is now as valuable for crushing purposes as the "tame stone," and by some producers is held to be preferable, for some of it is found to yield on crushing a more nearly cubical fragment than the "tame stone," which tends to crack into thin chips when crushed.

Within the city of Joliet; and for 2 or 3 miles north and south from its center, the quarrying industry is active, about 15 important openings having been noted in September, 1907. On the west bluff of Desplaines Valley, in the SE. $\frac{1}{4}$ sec. 33 , Lockport Township, the quarry of the Commercial Stone Company shows the following section:

Section at quarry of Commercial Stone Company, near Joliet.

\begin{tabular}{|c|c|}
\hline Soil..... & $\begin{array}{c}\text { Feet } \\
1-2\end{array}$ \\
\hline Gravel................... & 4 \\
\hline $\begin{array}{l}\text { Iagnesian limestone, buff colored, weathered, thin bedded, and } \\
\text { cherty } \ldots \ldots\end{array}$ & \\
\hline Iagnesian limestone, light gray, even grained, in medium to thick & \\
\hline
\end{tabular}

These beds dip $2^{\circ}$ to $3^{\circ} \mathrm{NW}$., and are cut by two very prominent sets of joints. One of these sets extends N. $40^{\circ} \mathrm{E}$. and the joint planes are vertical, clean cut, or enlarged by solution, and are spaced at intervals of 46 to 50 feet. The other set of joints extends practically at right angles to the first set, but the planes are less regular and persistent, and they pitch steeply to the southeast. Water descending from the gravel above the limestone has opened numerous large channels through the rock, and many of these are filled with clay when opened in quarrying. Along one joint plane so much rock has been removed by solution that the upper beds have caved down into the opening. Rubble is the principal product of the quarry at present.

On the east side of the valley, about one-fourth mile south of the north line of Joliet Township, a quarry and crushing plant is operated by the State Penitentiary. The quarry is excavated below the level of the valley bottom, and shows the following section:

Section at State Penitentiary quarry, Joliet.

Black soil and limestone débris

1-2

Argillaceous limestone, thin bedded and flaggy, somewhat stained

to buff or light brown color . ............................

Magnesian limestone in fine grained, medium-thick, even beds....

Magnesian limestone, rough grained, irregularly bedded, in medium-

thick beds..........................................

Magnesian limestone, hard, in thin to medium-thick strata, irregularly bedded, with rough fracture and films of blue, hard, claylike material distributed through the mass. The color of the rock is light pink......................................... 
The rock obtained here is used for road making throughout the State.

The Western Stone Company operates a large quarry near South Richards street, in the southern part of Joliet. In this and neighboring quarries the Niagara limestone is exposed for more than onehalf mile along the Michigan Central and Elgin, Joliet and Eastern tracks to depths ranging from 15 to 50 feet. The following section shows the general character of the upper part of the rock and its cover at this place:

\section{General section at quarry of Western Stone Company, Joliet.}

Soil, gravel, peat, and calcareous clay, with minute shells.........

Magnesian limestone, thin bedded, flaggy, and weathered to yellow or buff color on top; the rock is even bedded and fine grained (tame stone). Lower beds become lighter colored and reach

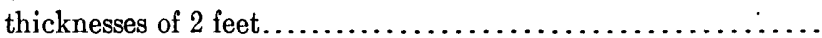

Magnesian and argillaceous gray limestone (wild rock) in roughsurfaced, irregular beds, 1 to 3 feet thick; mostly chert-free .... 10-15

Beds similar to above, but thicker bedded, and containing a little chert in small nodules, as well as considerable bluish-green argillaceous materials on the pitted surfaces of the beds........ 12-1.5

The "tame stone" is used for dimension stone, flagstone, and curbs. The "wild rock" is entirely crushed. It is very hard, and crushes into well-shaped lumps.

The beds are jointed, the planes trending nearly due northwestsoutheast and northeast-southwest. The first-mentioned joints appear usually to be inclined to the northeast, but those of the second set are more commonly vertical. There has been rather general though slight slipping of the strata on the northwest-southeast joint planes. The displacement reaches 2 inches in a number of places, and the downthrow is toward the direction of inclination of the joint plane, or usually. toward the northeast. Where the hade, or inclination, is in the opposite direction the downthrow is there found to be in the direction toward which the plane is inclined, or, in other words, the miniature fault.is everywhere a normal one. In working the rock advantage is taken of this general drop on the northeast side of the joint planes, as it is possible thus to pry loose and move slabs and blocks with greater facility than where there is no offsetting in the beds.

As nearly all the quarries at Joliet are comparatively shallow, few, if any, additional facts would be brought out by further descriptions. In general it is shown that cherty beds usually outcrop in the river bluff's, and that below these cherty beds there are alternations of noncherty "tame". and "wild" rock, and in places beds that are sparingly cherty at 25 feet or more below the level of the flood plain. 
Southwestward down Desplaines Valley to the mouth of Rock Run the normal magnesian-limestone character of the Niagara remains constant, although exposures below the south line of Joliet Township are fewer because of the presence of gravel terraces in the valley. In the vicinity of Rock Run, however, and extending southeastward to the vicinity of Millsdale, is a bed of shale very similar to the Maquoketa shale that lies below the Niagara formation. About 11 feet of this shale is exposed at the pit of the Millsdale Pressed Brick Company on the edge of the valley one-half mile east of Millsdale station. To the southwest of and stratigraphically below this shale lies a coarse-grained, roughly weathering fossiliferous limestone. It is cherty and in places contains large numbers of calcite nodules. This rock is exposed in the wagon road near Desplaines River south of Millsdale, below the Atchison, Topeka and Santa Fe Railway culvert 1 mile southwest" of Millsdale; in Rock Run just below the bridge of the Chicago, Rock Island and Pacific Railway; along Dupage River above the Rock Island Railway bridge, and at other places in the vicinity. Fossils collected from the exposure on Rock Run, where the relations of the limestone to the shale are very clear, and from the Millsdale locality, were submitted to Dr. Stuart Weller of the Illinois Geological Survey, and were pronounced by him to be Niagara forms. The shale did not yield any fossils where examined. The limestone below the shale is very dissimilar to Niagara limestone. It bears some resemblance to the Galena limestone, but unless further detailed studies demonstrate the contrary, the rock must be considered as belonging to the Niagara formation, on the paleontologic evidence furnished by Doctor Weller.

From an economic standpoint this limestone below the shale bed can not be regarded as of present importance to the concrete industry for the following reasons: (a) Its texture is not sufficiently uniform, as it contains a mixture of calcite, magnesian limestone, and chert; and $(b)$ its outcrop area is too remote from markets to enable it to compete with the better Niagara limestone, which occurs in practically inexhaustible quantities in more advantageous situations. Therefore the survey of the Desplaines Valley for limestone concrete material available to the Chicago market was terminated with Millsdale as its southwestern limit.

The thickness of the Niagara limestone in a city well at Ottawa street and Crowley avenue, Joliet, was reported by the city engineer to be 220 feet. Below this the record showed a bed of shale 140 feet thick (Maquoketa), and next below was 225 feet of limestone (Galena). There is thus at Joliet no record of a thin bed of shale toward the base of the Niagara. 
On Fox River the Niagara rock was observed to outcrop at about six places, and inasmuch as no especial search was made for outcrops in the gravel district there are doubtless others. Two of these outcrops are on the east and west sides of Fox River about 1 mile north of the center of Batavia, and quarrying in a small way for local use has evidently been carried on here. Another outcrop was observed west of the river, in the northern part of St. Charles.

At South Elgin, on the west side of Fox River, the Niagara limestone comes to the surface of the valley bottom and is being exploited at the quarry of Magnus \& Hagel. The rock occurs in thin beds with irregular, horizontal, wavy bedding planes usually coated with thin seams of bluish-green clay. The rock breaks with irregular rough fracture and is rather cherty. At 20 feet below the top there are 3 feet of beds in which the chert nodules are large and almost predominate in the strata. The material is typically a "wild rock" and is highly magnesian. The top 5 to 10 feet of beds are weathered and stained to a buff color. The rock is sparingly fossiliferous and in places contains crystals of dolomite and pyrite.

On West Branch of Dupage River, three-fourths of a mile southwest of the railroad station at Naperville, is a small area of Niagara limestone exposed by this stream. The rock has been quarried extensively here in former years, but the workings are now abandoned and the pits are filled with water. The cover that was stripped ranged in thickness from 4 to 15 feet, principally of drift, and the cuts were from 40 to 70 feet deep. The quarries formerly furnished bridge stone, dimension stone, rubble, and crushed stone. The rock was apparently used largely in the construction of the older buildings at Naperville. Much of the rock obtained was massive bedded and even grained, and some was evidently cherty.

\section{CHEMICAL COMPOSITION.}

An important use to which the Niagara magnesian limestone is put in the vicinity of Chicago is as a flux in iron and steel making. Vast quantities of Lake Superior ore are smelted and the iron is converted into steel at the works of the Illinois Steel Company at South Chicago and Joliet. At Indiana Harbor, Ind., the plant of the Inland Steel Company has commenced operations, and the United States Steel Corporation is erecting works of such magnitude near the lake shore in northwestern Indiana that the construction of the new town of Gary has been begun. As the Lake ore contains a very low percentage of lime and magnesia, good fluxing stone is very much in demand and 
many working analyses of the Niagara rock are available. A few of these are given below:

Analyses of Niagara limestone.

\begin{tabular}{|c|c|c|c|c|c|c|c|c|c|c|c|c|c|}
\hline No. & $\mathrm{SiO}_{2}$ & $\mathrm{Al}_{2} \mathrm{O}_{3}$ & $\mathrm{Fe}_{2} \mathrm{O}_{3}$. & MnO. & $\mathrm{CaCO}_{3} a$ & $\mathrm{MgCO}_{3} \cdot a$ & $\mathrm{Na}_{2} \mathrm{O}$ & $\mathrm{K}_{2} \mathrm{O}$. & $\mathrm{SO}_{3}$. & P. & s. & $\mathrm{H}_{2} \mathrm{O}$. & Authority. \\
\hline 1.. & 1.12 & 0.91 & 0.83 & & 54.73 & 42.79 & & & & 0.005 & 0.04 & & Illinois Steel \\
\hline & 1.23 & 55 & 37 & 0.03 & & & 19 & 14 & r & & & 0 & (U. S. Geol. S \\
\hline & 27.27 & 5.63 & 1.62 & .02 & 33. & 27.95 & .02 & 2.94 & Tr. & & & .26 & al-materia is \\
\hline $4 .$. & .40 & & .40 & & 59.40 & 39.80 & & & & Tr. & .04 & & Mariner \& Hos- \\
\hline 5. & .70 & & .90 & & 53.41 & 45.22 & & & & & & & Feathe rs t one \\
\hline 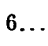 & 1.04 & .80 & .80 & & 54.82 & 43.13 & & & & & & & $\begin{array}{l}\text { Chicago. } \\
\text { Illinois. Steel }\end{array}$ \\
\hline $7 .$. & .28 & $\cdot \cdot$ & & & 55.38 & 43.93 & & & & & & & Inland Steel \\
\hline . & 1.10 & .93 & .86 & & 54.68 & 42.84 & & & & & & & $\begin{array}{l}\text { Harbor, Ind. } \\
\text { Illinois }\end{array}$ \\
\hline & 17.30 & 1.33 & .96 & & 36 & & & & & & & 1.00 & J.V.Q. Blaney. \\
\hline $10 .$. & $\begin{array}{l}1.99 \\
1.90\end{array}$ & $\begin{array}{l}.62 \\
.64\end{array}$ & $\begin{array}{l}1.15 \\
2.08\end{array}$ & 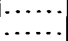 & $\begin{array}{l}53.73 \\
52.61\end{array}$ & $\begin{array}{l}42.13 \\
41.84\end{array}$ & & & .... & $\begin{array}{l}.014 \\
.012\end{array}$ & .054 & ..... & \\
\hline & & & & & & & & & & & & & \\
\hline
\end{tabular}

a The lime and magnesia are here given in terms of the carbonate in order more readily to show how closely the composition of the rock approaches that of dolomite $\left(\mathrm{CaCO}_{3}=54.35\right.$ per cent; $\mathrm{MgCO}_{3}=45.65$ per cent).

1. From Dolese \& Shepard, Hawthorne quarry. Average of 18 analyses made on 878 carloads of stone in 1904 .

2. From basal beds at quarry of Brownell Improvement Co., Thornton. Rock is burned for lime.

3. From beds near middle of face of same quarry at Thornton. Rock can not be burned for lime."

4 and 5. Samples averaged from top 20-foot face at quarry of Federal Stone Co., Lagrange.

6. From Dolese \& Shepard, McCook quarry. Average of 36 analyses made on 803 carloads of stone in 1903.

7. From United States Crushed Stone Co., McCook. A verage of 6 analyses

8. From Dolese \& Shepard, Gary (IIl.) quarry. Average of 27 analyses made on 811 carloads of stone in 1903.

9. "Athens marble" from Lemont. Analysis furnished by Western Stone Co.

10 arid 11. Averaged analyses from quarry of Joliet Flux Stone Co., Romeo.

\section{GENERAL METHODS OF PREPARATION OF CRUSHED STONE.}

As nearly all the stone quarries in the Chicago district are in the form of pits excavated below the surrounding surface, the problems that have to be met are those peculiar to this type of quarry, and therefore the same fundamental principles are very generally observed. Methods vary considerably, however, throughout the district, according to the size of the quarry, its stage of development, the character of the rock, and the uses for which it is intended. In the initial stage the rock must be stripped of its overlying cover of soil and glacial débris. This is usually done by means of scrapers, but in the case of deposits 5 or 6 feet thick a steam shovel may be advantageously employed, particularly where the same shovel can be used for further work in handling the broken upper courses of rock. A thickness of 6 feet of cover is considered to be about the maximum limit profitable to strip at present. Drilling and blasting are universally employed to break up the rock, but here again occurs a wide diversity in practice. Both steam and compressed air are used in drilling, the latter 
preferably on long lines. The depth drilled ranges from $3 \frac{1}{2}$ feet to 24 feet. The charges also vary considerably in number, character, and strength. Most quarrymen use dynamite, although a few prefer black powder. The thoroughness with which the stone is broken up in blasting contributes toward the economical operation of a quarry. At some quarries large quantities of rock are shot out in huge blocks and these require reblasting and also a great deal of subsequent breaking with sledges to reduce the stone to a suitable size for the crusher. At one quarry, operated by an expert powder man, holes are drilled 2 feet apart, 4 to 10 feet from the face, in two rows, and set "staggering." At times as many as 100 shots are fired at once, and as a result very little reblasting is found necessary.

At practically all the quarries equipped with crushers, the crushers are situated at the surface, above the quarry, so that the rock has to be raised to them. At the greater number of quarries the broken rock is loaded by hand and hauled in automatically dumping cars up an incline by cable. At a few of the larger but shallow quarries the rock is loaded by steam shovels. Rock for lime burning or for rubble is generally selected and loaded by hand. In very deep pits platform elevators are in use, so built that they carry one or two loaded cars at a time. The character and capacity of the tram cars vary according to the general character of the equipment of the quarry, cars of wood or steel that hold 2 to 3 yards of broken stone being used. In crushing the stone several types of equipment are employed, but each aims to break the stone and to separate it into definite sizes by dry screening. For concrete purposes the stone should be as free from dust as it is possible to make it, and therefore plants which pay especial attention to the screening end of the process produce the best grade of concrete material.

One of the largest and most efficient plants in the district consists of two mills, one equipped with a No. 8 and the other with a No. $7 \frac{1}{2}$ Gates gyratory crusher, besides two No. 5 crushers each. The capacity of the two sets of crushers is respectively about 200 tons and 170 tons per hour, giving an average daily output of about 3,000 tons. The rock is put through rotary cylindrical steel screens, that give the following sizes: "Screenings," less than one-fourth inch; "roofing," one-fourth to one-half inch; "concrete," one-half to 1 inch; fine medium, 1 inch to $1 \frac{1}{2}$ inches; "medium," $1 \frac{1}{2}$ to $2 \frac{1}{2}$ inches; macadam, $2 \frac{1}{2}$ to 5 inches; and fluxing stone, 5 to 7 inches, the last size being rejected by the coarsest screen. Crushed stone is screened dry as contrasted with the washing process to which gravel is subjected when crushed and screened. As a rule the broken stone comes from the quarry with little or no foreign material, and whenever a clay seam or pocket is encountered it is cheaper to extract that material in the quarry than to remove it by, washing in the mill. Another 
large, newly built plant is equipped with one No. 8, two No. 5, and two No. 3 crushers and four screens. The reported product of this mill at the start was 1,600 to 3,000 cubic yards ${ }^{a}$ per day. One plant, equipped with one No. $7 \frac{1}{2}$ and two No. 4 McCully crushers, is reported to average 700 to 800 cubic yards per day of stone in five grades ranging from seven-eighths inch to 2 inches, besides screenings. Still another system of crushers in use is the Austin. At a plant equipped with one Austin No. 7, one Austin No. 4, one Gates No.. 3 crusher and two screens, the capacity per day is reported to be 300 yards.

\section{AVAILABLE LIMEST'ONE.}

The reserves of Niagara limestone in the Chicago district suitable for crushing into concrete material are practically inexhaustible. The supply in those city quarries that are hemmed in by streets and buildings is of course limited because city values will prevent areal enlargement of the pits, and they must be sunk deeper and deeper until they reach the limit of depth beyond which it is impracticable to raise rock, or until they reach the underlying shale. It is thought that the deepest quarries still have more than 100 feet of stone below their lowest levels, so that their continuation is mainly a question of costs, and in such quarries slightly increased costs of working are offset by central location and consequent decrease of cost of delivery to consumers.

In the discussion of the Niagara formation the distribution of available material has been outlined in connection with the description of working quarries. The main areas are shown on the map (fig. 24). The Desplaines Valley will probably always continue to furnish the greater supply of crushed stone, although there is room for much more excavation at Stony Island, Blue Island, Thornton, Lagrange, Naperville, and at points on Fox River.

Sanitary and ship canal spoil bank.-The broken stone piled along the rock-cut portion of the sanitary and ship canal constitutes an important stock of material that is available without having to be quarried. Tests of this material made by the Chicago city engineering department show that although the rock tested was necessarily taken from the outside, or weathered portion of the spoil bank, the character still remains good, and it must reasonably be expected that on the inside of the pile also it should be sound. (See page 389.) From Willow Springs to Lockport, a distance of 15 miles, the channel is cut through rock. It is 160 feet wide at the bottom and 162 feet wide at water line, and the depth in this section averages 35 feet. The grade of the channel is $3 \frac{1}{4}$ inches to the mile. The walls in the rock cut, having been cut by channeling machines, are smooth and perpendicular, with offsets. The total amount of solid rock that has been excavated 
is estimated by the engineers of the sanitary district to aggregate $12,912,000$ cubic yards. When broken up by blasting and piled in miniature mountain masses along the borders of the channel, the cubic contents of the material was largely increased. After nearly eight years of construction work, water was turned into the canal January 2,1900 , and for several years afterwards these mountains of stone piled along the right of way were regarded simply as an incumbrance. Recently it has been planned by the sanitary district board of trustees to turn this incumbrance into an asset by selling the broken rock to parties who will erect crushers and convert it into stone for concrete, paving, etc.

The board has estimated that there are about 20,000,000 cubic yards of stone in these piles-material enough to construct concrete docks from the mouth of Chicago River throughout the length of the canal, Desplaines and Illinois rivers to St. Louis, following the course of the proposed inland deep waterway, or else the material could be used to construct a chain of concrete factory buildings and warehouses from Robey street, Chicago, where the canal begins, to Joliet, 40 miles inland. The price basis on which the rock is to be disposed of by the sanitary district is $10 \frac{1}{2}$ cents a yard and a portion of the net profits. $^{a}$ A beginning has already been made toward utilizing this spoil-bank stone. As mentioned on page 389, the Western Stone Company is operating two crushers near the county line west of Lemont, and east of Lemont the broken stone is being removed from the bank by steam shovel and shipped, without crushing, via barges on the canal to the lake front at Lincoln Park, Chicago, where it is used for riprap. This rock compares favorably in quality with freshly quarried limestone.

Importance to proposed deep waterway.-All the available rock, both in the spoil bank and in place in the Desplaines Valley, is adjacent to rail and water transportation facilities and can be cheaply handled. These facts, in connection with the almost limitless reserves of highquality stone, are not only of importance in assuring to Chicago a plentiful supply of stone for crushing, but they have an important bearing on the economical construction of the proposed deep waterway from the Lakes to the Gulf. It must be remembered that for most of its length Illinois River, along which much concrete work would be necessary, flows through the coal-measure area, cutting into soft shale and sandstone and exposing few limestone beds thick enough to quarry until the area of Mississippian rocks is reached, near its mouth. Therefore supplies of crushed stone for concrete work would have to be obtained at the extremities of this inland waterway, and the Chicago end may be.said to be well prepared to furnish the larger share of the needed material. 


\section{GLACIAL SAND AND GRAVEL (OUTWASH AND MORAINE MATERIALS).}

\section{CHARACTER AND DISTRIBUTION.}

Another source of concrete materials in the Chicago district may be found in the sand and gravel of glacial origin, derived mainly from the drift of Wisconsin age. 'The deposits here considered lie mainly within the morainal areas, but the character of many of the deposits is that of outwash material - that is, nearly clay-free, stratified gravel and sand, as distinguished from the morainal material, which is composed of clay, bowlders, and sand mingled in a confused mass. While the moraines of the Wisconsin drift sheet in northeastern Illinois and southeastern Wisconsin were being formed, there were streams of water issuing from the ice sheet and escaping to Mississippi River by way of Rock River and the tributaries of Illinois River, the Fox, Dupage, Desplaines, and Kankakee. These streams became overburdened with sand, gravel, and silt derived from the glaciers, and as a result filled up their beds and valley bottoms to a greater or less extent. In some places they spread out the detritus in terraces, or subsequently cut a new channel through the filled-up valley, leaving residual terraces on the valley sides.

The principal deposits of this type which are of economic importance in the Chicago district are situated, as shown on the map (fig. 24), along Fox River between Camp Lake, Wis., and St. Charles, Ill.; on Desplaines River at Libertyville and at and below Joliet, and on Long Run, Spring Creek, and Hickory Creek, small eastern tributaries of Desplaines River near Joliet. Beyond the area of the map, in the valley of Rock River, outwash deposits are exploited for the Chicago market at Janesville, Wis., and in Winnebago County, Ill., 1 mile south of Beloit, Wis. Besides these outwash deposits there is a thick deposit of morainal gravel being worked at Fontana, at the west end of Lake Geneva,Wis.

The important Fox River sand and gravel deposits in Illinois are near Cary, Algonquin, Carpentersville, Elgin, and St. Charles, and the general characteristics of the deposits being. worked may be indicated by descriptions of a few typical workings. At Cary the deposits form a terrace on the north side of the river both east and west of the Chicago and Northwestern Railway, and are worked by the railway and the Lake Shore Sand Company. East of the railway the Lake Shore Sand Company has opened a face nearly one-half mile long. The present workings. are at the northwest end of the face and disclose a bank about 40 feet high. The material ranges from fine quartz sand to bowlders, a few of which are 18 inches in diameter or larger. The bank is reported to average 75 per cent 
sand and 25 per cent gravel, including everything larger than torpedo sand. The upper 25 feet of the bank carries more gravel than that below, and in the middle third is found the coarsest gravel. There are a few ledges of partly consolidated gravel conglomerate, and locally near the base of the cut is 4 to 6 feet of sand that has been indurated by a dark ferruginous cement, forming a sandstone. Such hardened crusts of sand and gravel are termed by the quarrymen "hardpan" and this material has to be discarded, as the pit is worked by steam shovel and the hardpan ledges can not be cut by the shovel nor economically broken by blasting. West of the Chicago and Northwestern Railway the Lake Shore Sand Company is working a pit about 75 feet deep, below which water and quicksand are encountered. The material here runs irregularly as to its content of sand and gravel, but will probably yield a higher percentage of sand than the bank east of the railway. The middle third (vertically) will probably yield 75 per cent of sand, the upper part a little less, and the lower part a great deal more. The character of the material varies greatly from place to place, lenses or pockets of sand and gravel occurring without apparent system. For instance, on the southeast side of the present pit there is a bed of fine sand, extending 30 to 40 feet above the bottom, whereas on the opposite side of the pit alternate layers of gravel and sand extend down within 10 or 15 feet of the base. At this cut there is apparently no "hardpan" present, a fact which also illustrates the variability of the local deposits.

For $2 \frac{1}{2}$ miles north of Algonquin sand and gravel are found on the sides of the small valley through which the Chicago and Northwestern Railway passes. Northward toward Crystal Lake the deposits of sand and gravel are reported to grow thinner. The deposits at present worked form the shoulder or border of the upland lying between this small valley and Fox River to the east. At the bank of the Etna Sand and Gravel Company, about 2 miles north of Algonquin, the heaviest deposit of sand and gravel is about 50 feet thick, with 2 to 4 feet of soil above and reddish clay below. This clay floor is about 25 feet above the creek bed. The banks worked here are from 20 to 40 feet thick, and they. yield on an average about one-third gravel and two-thirds sand. The gravel runs rather small and contains only a few bowlders, which are found at the base of the deposit. At the top of the deposit and following the contour of its surface is a bed 5 to 10 feet thick containing an equal if not greater quantity of gravel than sand. Below this the gravel and sand are interstratified in layers from a few inches to 4 or 5 feet thick, and also are mixed together. Cross-bedding is seen at many places in the section and some beds having this structure are so firmly consoli- 
dated by a calcareous cement as to form hard conglomerate or hard sandstone. In places this material has assumed tubular or "pipy" shapes. Such material softens with exposure but does not disintegrate entirely. The finest sand is nearly all made up of quartz and other crystalline rock, but gives some effervescence in acid. The coarse sand effervesces more freely, showing a large proportion of calcareous material. A carload of 1-inch gravel showed nearly 20 per cent (roughly estimated) of crystalline pebbles, the remainder being mainly dolomite with some chert.

On the east side of Fox River, $1 \frac{1}{2}$ miles below Algonquin, is the pit of the Richardson Sand Company. The bank worked here is in the top 50 feet of the range of hills that rise 150 feet above Fox River at this place. A general section of the material exposed in the cut is as follows:

General section at Richardson Sand Company's pit near Algonquin.

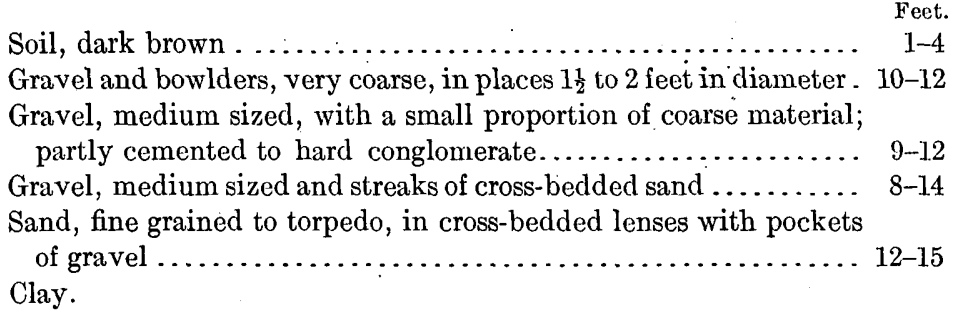

This deposit contains an unusual proportion of coarse material, some of the bowlders being angular slabs of Niagara dolomite so thick as to show more than one stratum. Many of the large bowlders are of crystalline rock. The above section can not be regarded as persistent, however, for the variation in the character of material from point to point is very abrupt. The yield of sand and gravel is about equal in quantity, although there is a larger proportion of 'sand than gravel in the bank. This is due to the fact that part of the sand is too fine to be caught by present methods of separation and is consequently washed away with clay and silt to the settling pond. When stripped, the surface of this gravel is almost level.

From Carpentersville to Algonquin on the east side of Fox River deposits of sand and gravel are found in places, but not continuously. For much of the distance the clay which underlies the gravel rises high and lies nearly parallel to the contour of the hills, so that the gravel is too thin to be profitably worked. On the west side of Fox River valley there are also high bluffs, largely of clay, on top of which sand and gravel occur, but the deposits have not yet been worked because of lack of transportation facilities and irregularity in thickness of the material, and because the present demand is supplied from deposits more advantageously situated. 
South of Elgin there are sand and gravel deposits worked on the west side of Fox River near Coleman and 1 mile north of St. Charles; and on the east side of the river at Hammond and $1 \frac{1}{2}$ miles east of Coleman.

Near Coleman, between the Illinois Central Railroad and Fox River, gravel deposits are worked by the Richardson Sand Company. At this pit the working face is 15 to 30 feet thick, although the clay which underlies the deposits has so uneven a surface that the gravels thin in places to 6 or 8 feet. Overlying the sand and gravel is 4 to 5 feet of fine-grained silt. The material being worked yields about 3 parts of sand to 1 part of gravel. The gravel is mainly small in size, and the sand is rather coarse, mostly a torpedo grade. The 1-inch to $1 \frac{1}{2}$-inch gravel appears to contain 10 to 15 per cent of crystalline material, and the finer gravel a still higher percentage. At the base of the deposit are many rather large bowlders of dolomite and granite, 2 to 3 feet in diameter. The sand and gravel instead of occurring in separate strata as in the region near Algonquin, are rather uniformly mixed together, and no "hardpan" or consolidated conglomerate was noted.

East of the river and south of the Chicago, Milwaukee and St. Paul Railway at Hammond is the pit and plant of the Chicago Gravel Company. The sand-gravel deposit lies upon a clay floor that is slightly uneven. The deposit reaches a total, thickness of 27 feet in places and the stripping averages about 2 feet. A few bowlders 2 to 3 feet in diameter occur at the base, but in the bank the gravel is unusually uniform in size, rarely running into large cobblestones. The sand is a good sharp torpedo, not very fine. It contains a small proportion of lime, reported to be about 2 per cent. The proportion of sand to gravel in the bank is said to average about 55 to 45 . No conglomerate nor "hardpan" was noted, but lenses of clay were found to occur in the bank. One of these noted at the time of visit was 6 feet thick in a bank 22 feet in length. Most of this clay, fine-grained and siltlike material, can be kept out of the product by a skillfully manipulated steam shovel, although some of it is certain to be loaded with the sand and gravel and it can not be eliminated entirely in the washing.

One mile north of St. Charles, on the west side of Fox River, is the pit of the American Sand and Gravel Company. The deposits here reach a thickness of 35 feet. Below the sand and gravel water is encountered in quicksand, before the underlying clay is reached. The base of the deposit is therefore low, not far above the level of Fox River and of the creek to the south of the pit. Gravel and sand in about equal parts appear to constitute the bulk of the material. The gravel ranges from small to coarse sizes, and some cobblestones go to the crusher in nearly every yard of material excavated.

47076--Bull. 340-0s-26 
Notes on the gravel pits along Fox River would not be complete without mention of two points just north of the State line in Kenosha County, Wis. At Capp Lake are some abandoned pits owned by the Wisconsin Central Railway. The deposits here are reported to have been thoroughly prospected, but to have proved not to be of promising thickness nor cleanness. Below 2 to 3 feet of soil there lies about 5 feet of fairly good gravel in the higher parts of the bank. Below this there are alternate seams of clay and quicksand containing heavy bowlders. Washing and crushing would therefore be involved to too great an extent for practical purposes.

Near Wilmot, Wis., is a pit the output from which is taken by the -American Sand and Gravel Company. The pit is a straight cut into a terrace of Fox River and shows the following section:

Section of gravel pit near Wilmot, Wis.

Feet.

1. Soil ........................................ $1-2$

2. Gravel and sand. The gravel is clean and contains about 15 per cent of crystalline rock, the remainder being dolomite. About 15 per cent of the gravel runs larger than 2 inches.... 8-14

3. Quicksand and silt, very fine-grained material containing about 60 per cent of quartz, the balance being clay minerals..... 14-15

4. Gravel, similar to the upper gravel bed (No. 2)............ 20

5. Sand, fine grained, to quicksand. In the aggregate this bed is coarser than bed No. 3, contains a higher percentage of silica

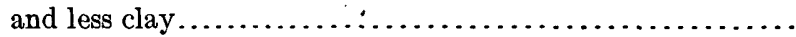

6. Quicksand and water.

The beds of quicksand inclosed in the gravel vary in thickness and do not conform in contour to the present surface of the terrace. In general they appear to dip toward the northeast and to pinch out in various directions as if lens-shaped. The material is reported to be composed of the various grades in about the following proportions:

Proportions of sand and gravel in pit at Wilmot, Wis.

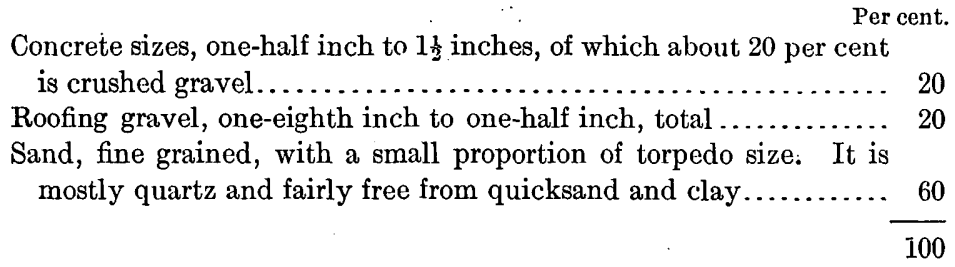

On the west side of Desplaines River at Libertyville is the sand and gravel pit of the Lake Shore Sand Company. The deposits seem to be mainly west of the river in this vicinity and are comparatively thin. This deposit is the thickest in the locality, and it ranges from 5 or 6 to 25 feet in thickness above water level. Test wells are reported by the operators of the pit to show 20 feet of gravel below water level. The water level varies 1 to 2 feet during the year, and 
the cut is deeper or shallower accordingly. A section made at the southeast end of the cut, where material was being obtained October 3,1907 , is as follows:

Section of sand and gravel bank at Libertyville.

Feet.

Soil.................................. $\begin{array}{r}\text { Feet. } \\ 1-2\end{array}$

Fine sand, loam, and a little gravel..................... $0-4$

Clay lens, saucer-shaped in profile....................... $0-1$

Gravel and torpedo sand in alternate beds, $1 \frac{1}{4}$ to 2 feet thick, crossbedding common. The gravel is mostly smaller than 4 inches. The proportion of sand to gravel ranges from 2 to 1 to 1 to 1 , but

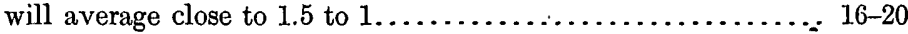

Gravel, sand, and water (reported 20 feet to clay).

The usual sizes of sand and gravel are produced here and an additional product worthy of note is the unwashed run-of-bank sand and gravel, including all material smaller than $1 \frac{1}{4}$ inches that is used in road making. It is stated that the loam present exerts a cementing action that makes the material of value as a bond when laid in alternate layers with crushed stone in macadamizing roads. Unsuccessful efforts have been made to pump the sand and gravel that lie below water level, the result being that the pumps were soon choked by the gravel. It is proposed to attempt at some future time the dredging of these deposits. It would seem worth while to utilize these submerged materials, as the visible supply of gravel above water level is diminishing rapidly in this locality.

Farther down the Desplaines Valley deposits of sand, gravel, and bowlders are scattered at irregular intervals and many of these are worked from time to time in a small way for local purposes. One such deposit is about a mile north of Willow Springs. The main deposits, those that are at present affording material sufficient for the operation of crushing plants, are at and below Joliet. Hickory and Spring creeks have built up deposits of gravel in their valleys and in the Desplaines Valley near the junction of the two creeks.

On East Washington street, Joliet, the Chicago Gravel Company operates a pit and crusher: The deposit varies greatly from place to place.

The gravel and sand are cross-bedded in places. The clay content of the gravel averages about 20 per cent. The gravel consists mostly of dolomite, with a few crystalline pebbles. In places the material is hardened by calcareous cement to a conglomerate. The sand is fine to coarse grained and of dark color. It contains comparatively a high percentage of limestone and dolomite grains and of clay, with relatively a low proportion of silica.

The clay seams thin out to the north and the south. Characteristics of the bank on the east side of the pit are that no beds of fine sand 
appear in the section and that the gravels are more even bedded than elsewhere in the pit.

Another plant of the Chicago Gravel Company is on the east side of the valley about $1 \frac{1}{2}$ miles above Millsdale, adjacent to the Santa $\mathrm{Fe}$ and Chicago and Alton railways. The deposit worked here is in the form of a terrace or bar in the Desplaines Valley and consists of material ranging from sand and loam to bowlders 2 feet in diameter. The bottom of the cut is in gravel, but reaches ground-water level, which is practically at the level of the water in the river and fluctuates with it. The deposit is about 10 feet thick on one side of the cut and 20 feet thick on the other. The gravel and bowlders are composed principally of hard dolomite, but about 5 per cent of crystalline material is present. The loam and sand are highly calcareous. The sand and gravel deposits in this vicinity and southward to the mouth of the Dupage are extensive, and thus far have been only very slightly utilized.

Certain important deposits of sand and gravel which, although at considerable distance from Chicago, are so directly connected by railroads with the city that they are worked to advantage should be mentioned in these notes. Such localities are in southeastern Wisconsin, at Fontana, Janesville, and Beloit.

At Fontana, at the west end of Lake Geneva, the Lake Geneva Gravel and Sand Company is exploiting a thick gravel bank. The deposit is part of the Darien moraine of the Delavan lobe of the Lake Michigan glacier, according to Alden. ${ }^{a}$ The maximum thickness of the cut is about 90 feet. Two or three feet of soil is stripped from the top by means of scrapers. A general section shown by the cut is as follows:

General section of gravel pit at Fontana, Wis.

Feet.

Soil with a few large bowlders at base...................... $2-4$

Clayey, loamy, fine sand, of brownish color, containing a little

- gravel......................................... $6-7$

Coarse, cobblestone gravel........................ $\quad 20$

Sand, thin ledge................................... $1-3$

Gravel, rather coarse, with some sand, mainly concealed by talus

to bottom of cut.................................. 30-60

The gravel runs unusually large, as compared with the Fox River and Rock River deposits. In the larger gravel there is a fairly large proportion, perhaps 15 per cent, of crystalline rocks, many of which are dark colored. The remainder of the gravel is mostly dolomite and limestone, largely of Niagara age. The proportion of gravel to sand is reported by the operators of the pit to run about 3 to 2 , and in places a still higher proportion of gravel is found. At the west end of the pit there is considerable firmly cemented conglomerate.

a Alden, W. C., The Delavan lobe of the Lake Michigan glacier: Prof. Paper U. S. Geol. Survey No. 34, 1905, Pls. IV, V, and X. 
There are apparently similar deposits still undeveloped in many of the hills at the west end of Lake Geneva, although none are so easily accessible as the bank just described.

Near Janesville, Wis., the outwash deposits of Rock River valley and tributary valleys are worked for sand and gravel. On South Main street, about 1 mile southeast of the middle of Janesville, a sand and gravel bank is exploited for the manufacture of sand-lime brick, cement shingles, and concrete blocks and posts. The face of the bank is about 25 feet in height. The upper 8 to 10 feet carries sand and gravel in the proportion of about 5 to 3 , but below this the ratio increases to about 10 to 1 . The gravel is small, few of the pebbles exceeding 3 or 4 inches in diameter. The material is very clean, and the sand is rather fine and composed almost entirely of quartz.

On the line of the Chicago, Milwaukee and St. Paul Railway, about $2 \frac{1}{2}$ miles east of Janesville, is a sand and gravel bank worked by the Knickerbocker Ice Company. The face of the bank is 50 to 70 feet in height. The material consists of small, clean gravel and clean quartz sand, much of which is of rather fine grain. The upper half of the bank is reported to carry sand and gravel in about equal quantities, but in the lower part sand predominates in the ratio of about 5 to 2 . The sand occurs in beds of fine to torpedo size and in beds with gravel; and at the bottom is a sand bed probably 25 feet thick, only 12 feet of which is utilized, as the material is a little too fine for torpedo size. The normal stripping is 2 to 4 feet, but in ravines that cut down into the deposit it will run as thick as 10 feet. The gravel rarely runs larger than 3 or 4 inches and yields concrete gravel containing 50 per cent or more of crushed rock. The product goes mainly to Chicago markets.

About 1 mile south of Beloit, Wis., in Winnebago County, Ill., is situated, the sand and gravel bank of the Attwood-Davis Company. This bank is on the east side of the Chicago and Northwestern Railway main line and is in the Rock River valley. The cut extends about one-third of a mile from north to south and is about 35 feet in height. The gravel is overlain by $1 \frac{1}{2}$ to 2 feet of black soil at the north, but to the south and east there is a bed of fine sand, 6 to 12 feet thick between the gravel and the top soil. This bed of sand forms a low ridge and also fills a shallow depression in the surface of the deposit. It is troublesome, as the sand is too fine for torpedo size and does not contain sufficient clay, except in small pockets, to make a molding sand. Below this, gravel and gravelly sand alternate in layers 2 to 3 feet thick. The gravel ranges in size from small to medium, 4-inch pebbles being about the largest. About 15 per cent of foreign crystalline material is present in the gravel. The cut is worked to the level of the underflow in the valley, but sand and gravel are reported to extend at least 50 feet farther down, as determined by a well point. The average run of the bank, 
as reported by the superintendent of the pit, is about 3 parts of sand to 2 of gravel. About 40 per cent of the concrete sizes produced consist of crushed gravel.

Besides the sand and gravel pits here noted, there are many small pits scattered here and there in the suburbs of Chicago worked by pick and shovel, with wagon haulage, to supply local needs. Many of these pits are in the extinct beaches of Lake Michigan, several miles from the present shore line. The location of these old beaches is shown in the areal geology maps of the Chicago geologic folio.

\section{GENERAL METHODS OF PREPARATION OF SAND AND GRAVEL.}

The preparation of cleaned sand and gravel begins with its excavation from pit or bank, and involves moving from pit to mill, screening to separate the sand and smaller gravel, crushing to reduce the small bowlders and gravel larger than $1 \frac{1}{2}$ or 2 inches in diameter, and washing to free the material of silt, clay, organic matter, and resultant discoloration. The method of handling the material depends somewhat on local conditions.

On reaching the crushing plant the gravel is screened under a stream of water. A set of screens usually comprises screens having some or all of the following sizes of perforations: 2-inch, $1 \frac{1}{2}$-inch, 1 -inch, $\frac{3}{4}$-inch, $\frac{3}{8}$-inch, and $\frac{1}{3}$-inch. They are of both rotating and stationary types.

After the gravel and sand have been sorted by screening, crushing, and washing, into the required sizes, the material is stored in bins which are readily emptied through spouts by gravity into cars on a convenient siding. By discharging two or more bins at once into the same car, and by regulating the rate of flow of sand and differently sized gravel, a mixture containing these materials in almost any desired proportion can be obtained, as, for instance, a mixture that will be suitable for concrete on the addition of the required quantity of Portland cement. During the winter months, when freezing interferes with washing operations, dry screens are used, when needed, at several plants in the district.

At the majority of plants in the district materials are separated into sizes about as follows: Torpedo sand (grains that pass $\frac{3}{8}$-inch sieve), roofing gravel (passing $\frac{1}{2}$-inch but not $\frac{3}{8}$-inch), and concrete gravel (passing $1 \frac{1}{2}$-inch but not $\frac{1}{2}$-inch). There is some variation from these sizes, of course, and larger sizes than $1 \frac{1}{2}$-inch are produced. The proportion of gravel of concrete size, which is sharp and angular as a result of crushing, depends on the coarseness of the deposit. Where the percentage of gravel in the bank is high and a large proportion of it is more than $1 \frac{1}{2}$ inches in diameter, the proportion of crushed stone in the product is of course relatively high, and has been known to reach 60 per cent. 
An interesting use to which the coarser gravel is put is as a flux in iron melting at Carpentersville, Ill., and this is possible because of the large percentage of dolomite pebbles in the gravel.

An important factor in the sand and gravel business is an adequate supply of water. Some plants are situated so close to Fox or Desplaines River that they may obtain water by pumping directly from the stream. Others reach an underflow at the base of the pit, or the base of the pit may be determined by water-saturated sand and gravel, and in such places an abundance of water may be obtained by driving pipes a few feet into the water-bearing gravel and pumping therefrom. Less advantageously situated with respect to water supply are those banks that are remote from a stream or high on the valley rims, but usually in this well-watered country sufficient water may be caught in reservoirs so constructed as to receive the run-off from some gully or wet-weather stream, or such a reservoir may be partly supplied by pumping or by utilizing the flow of a small spring. Where conservation of water is necessary, settling basins must be constructed, and space must be provided for them. Water thus used over and over again can be kept fairly clean, but is hardly as desirable as a copious supply obtained from wells or from a clear, flowing stream such as Fox River.

\section{AVAILABLE SAND AND GRAVEL.}

In the foregoing portion of the text suggestions have been given as to possible extensions of workings along Fox and Desplaines rivers. In review it may be said that in the valley of Fox River, from the southern part of Kenosha County, Wis., to Geneva, Ill., and perhaps farther south, there are many unworked deposits of sand and gravel. A large part of the moraines and outwash deposits left by the melting of the glaciers in southeastern Wisconsin is made up of sand and gravel. The character of these extensive deposits has been discussed in detail by William C. Alden. ${ }^{a}$ Their distribution is shown on the maps accompanying his report. There are vast amounts of sand and gravel yet to be utilized in the tracts indicated. These deposits, especially the moraines, vary greatly in character, however, from point to point, and much of the material is not now readily accessible for transportation. In the Desplaines Valley the best deposits are found between Joliet and the mouth of Desplaines River. Proved but undeveloped deposits occur in the areas shown on the map forming fig. 24 (p. 384), but owing to its necessarily small scale it has been impossible to show locations in the desired detail. On account of the irregularities in deposition which are common to glacial material, more particularly to morainal deposits than to outwash gravels, although somewhat characteristic of the latter, it is essential that thorough prospecting be

a The Delavan lobe of the Lake Michigan glacier: Prof. Paper U. S. Geol. Survey No. 34, 1905. 
done before arrangements are begun to work a pit or bank on a large scale. A common method of prospecting a tract is to sink a number of test wells 3 to 5 feet in diameter and as deep as desired in order to determine the thickness of cover, proportion of gravel to sand, size and character of gravel, whether or not any clay or " hardpan " is present, whether or not the materials are mixed or stratified, at what depth water is encountered, total thickness of deposit, and all such factors as have a bearing on the economical development of the deposit. In many places such test wells have to be curbed by planks to prevent the loose wall material from caving in, and often it is impossible to remove the planks from the well, so strong is the compression exerted by the deposit.

\section{LAKE SHORE DEPOSITS.}

\section{AVAILABLE MATERIAL.}

Fine-grained sand occurs in inexhaustible quantity on the present beach of Lake Michigan, and in places there is more or less coarse sand and gravel mixed with it. As a source of supply for concrete material, however, these deposits are not now of great importance, for the following reasons: The sand is mostly of finer grain than torpedo sand, which is most desirable; the material requires special methods for the separation of sand and gravel; the deposits are constantly shifting with shore currents; and the occupancy of the lake front by docks, railroads, parks, boulevards, and private grounds has made much of the beach unavailable or too valuable to be exploited for sand and gravel.

At the south end of the lake, in Indiana, sand dunes have furnished much of the filling used in track elevation, and this area, together with a few others temporarily worked south and north of Chicago, is still furnishing supplies of sand for local use, chiefly for lime mortars and plaster.

\section{METHOD OF OBTAINING AND PREPARATION.}

At Waukegan sand and gravel are obtained in a unique manner from the beach deposit. The Waukegan Sand and Gravel Company was operating in August, 1907, a sand pump or "sand sucker" in a shallow lagoon between the Ludington Salt Company's docks and a spit occupied by the Elgin, Joliet and Eastern Railroad. The outfit consists of a centrifugal pump having a 6-inch intake and a 7-inch outlet pipe. The pump is driven by a 20-horsepower engine, and the whole apparatus is floated on a covered barge. Water, sand, and gravel as large as $3 \frac{1}{2}$-inch are together pumped from the bottom of the lagoon, and are discharged through a pipe of variable length into screens and thence into cars. It is possible to pump material from as 
great a depth as 20 feet, and to carry the delivery pipe to cars at least 600 feet distant, provided a slight fall is given the pipe. Gravel larger than $3 \frac{1}{2}$-inch is excluded by a screen over the mouth of the intake. Occasionally the gravel that passes into the pump clogs it and makes trouble. It is reported that the capacity of such a plant is about 10 to 35 yards per day of ten hours.

The character of the deposits worked near Waukegan varies from place to place and also from season to season. Some deposits have been found to yield only 2 to 4 per cent of gravel, whereas others have yielded $33 \frac{1}{3}$ per cent. The material being raised at Waukegan was clean and of good quality. The gravel was composed principally of dolomite, granite, dark crystalline pebbles, quartz, and chert. This material is used locally for the most part, although it is occasionally bought by Chicago dealers when an extra-clean gravel is required.

\section{TESTS OF MATERIALS.}

In a separate bulletin which is in preparation describing in greater detail the sources and character of the concrete materials produced in the Chicago district, it is expected to publish the results of official tests made on these materials at the structural-materials laboratories of the Survey at St. Louis.

In the office of the city engineer of Chicago there is available an instructive set of results of tests, mostly of the Niagara limestone, made by the testing division of the bureau of engineering of that city. These tests were made on a uniform basis, and afford valuable data (a) for comparison of the various samples of rock with each other; $(b)$ for comparison of broken stone taken from the spoil bank of the sanitary and ship canal with freshly quarried material; (c) for comparison of gravel concrete with concrete containing crushed stone; and (d) for general information as to the strength and wearing power of the limestone.

The sampling and testing of the materials were carried on under the immediate supervision of P. C. McArdle, city engineer of tests. Samples were taken from 31 localities, 14 of which were along the spoil bank of the sanitary and ship canal between Willow Springs and Lockport, and the remainder were from the various quarries delivering crushed stone and gravel to the Chicago market.

An analysis of the results of these tests shows that the average compressive strength on 6-inch concrete cubes of three spoil-bank samples of limestone is 66,444 pounds ( 1,846 pounds per square inch), whereas the average strength of the 17 quarry samples of limestone is 64,684 pounds (1,763 pounds per square inch). In the compressive test on limestone blocks 1 inch by 1 inch by $1 \frac{1}{2}$ inches the average strength with 14 spoil-bank samples is 11,834 pounds; that with the 17 quarry samples is 12,397 pounds. Similarly, in abrasion tests, the average 
loss of weight in 14 spoil-bank samples is 21 per cent; in the 17 quarry samples, 19.57 per cent.

Tests were also made on two cubes of crushed-gravel concrete, in one of which the gravel was of large size and in the other of small size. The results with the large gravel concrete were among the highest of all the tests made; the other cube showed a good average result.

The opinion of the city engineer of tests, based on these results and on several years of field experience in canal construction work, is that the rock taken from the spoil bank is in general as good as that taken from any of the quarries of the district. Rotten stone, however, may be found in almost any quarry, as well as in the spoil bank, and this is particularly true of the quarries in the Lemont district and of the spoil bank along sections 12 and 13 , but this rotten stone can be readily detected by the observer.

\section{IITERATURE AND MAPS.}

There is a long list of papers dealing with subjects mainly of purely scientific interest in connection with this area, but few of them have practical value in relation to the subject of concrete materials. In the following papers will be found useful data regarding the character and distribution of the limestone, sand, and gravel in the vicinity of Chicago:

Alden, Wilitam C. Description of the Chicago district: Geologic Atlas U. S., folio 81, U.S. Geol. Survey, 1902.

— The Delavan lobe of the Iake Michigan glacier: Prof. Paper U. S. Geol. Survey No. 34, 1905.

Ievverett, Frank. The water resources of Illinois: Seventeenth Ann. Rept. U. S. Geol. Survey, pt. 2, 1896, pp. 695-849.

- The Pleistocene features and deposits of the Chicago area: Bull. Chicago Acad. Sci. No. 2, Geol. and Nat. Hist. Survey, 1897.

- The Illinois glacial lobe: Mon. U. S. Geol. Survey, vol. 38, 1899.

The available United States Geological Survey topographic maps of portions of northeastern Illinois and southeastern Wisconsin include the following quadrangles, the first four of which compose the area described in the Chicago folio: Chicago, Riverside, Calumet, Desplaines, Wheaton, Joliet, Wilmington, Morris, Highwood, Waukegan, Racine, Silver Lake, Lake Geneva, Delavan, Shopiere, and Janesville. 


\title{
PORTLAND CEMENT MATERIALS NEAR EL PASO, TEX.
}

\author{
By G. B. Richardson.
}

\section{INTRODUC'TION.}

The considerable cost of Portland cement at El Paso, Tex., owing to its distance from the nearest plant, and the fact that this rapidly growing city is the commercial center of a large area, cause the local presence of the raw materials for making cement to be a matter of importance. The object of this paper is to call attention to large deposits of lime and clay materials in the vicinity of El Paso.

\section{GENERAL GEOLOGY.}

The geology of the El Paso region has already been outlined by the writer ${ }^{a}$ and for the present purpose the following sketch will suffice. The city of El Paso is situated in the Rio Grande valley, at the mouth of a narrow gap which the river has cut through highlands in passing from the Mesilla valley to the Hueco Bolson. The Franklin Mountains lie east of the gap and the Cerro de Muleros west of it. The Franklin Mountains are composed of sedimentary and igneous rocks which range in age from Cambrian to Cretaceous. The strata dip steeply westward and the mountains as a whole have the general characteristics of a Basin Range block, but they differ from the type by being complexly faulted internally. The Cerro de Muleros is a laccolithic mountain with a porphyry core flanked by Cretaceous sediments. This mountain also has been much faulted, especially contiguous to the pass through which the Rio Grande flows. The bolson deposits consist of gravel, sand, and clay, and similar materials also compose the flood plain of the river. Limestones are abundantly developed in the Franklin Mountains and both limestone and shale are present in the Cerro de Muleros and in outlying hills between the two mountains.

\footnotetext{
$a$ Richardson, G. B., Reconnaissance in Trans-Pecos Texas: Bull. No. 9, Univ. Texas Mineral
} Survey, 1904. 


\section{CLAY MATERIALS.}

The clay materials can be classed as bolson clay, flood-plain clay, and shale. The bolson clays are extremely irregular in their occurrence. They are locally exposed in the terraces above the river and numerous lenses of clay have been found in the wells which have been sunk in the Hueco Bolson. As yet none of these deposits have been developed.

Flood-plain clay occurs in several localities in the Rio Grande valley near El Paso. The material, derived from rocks that outcrop higher up in the drainage area of the river, has been brought down in suspension by the stream and deposited on the flood plain. In this manner deposits of clay intercalated with sand and gravel have accumulated, the mode of origin causing the deposits to be of irregular extent and composition. The beds range in thickness from a few inches to many feet, and in character from a rather pure clay to one containing large admixtures of sand. More or less organic matter also is usually present. The analysis of clay from Whites Spur, about 10 miles north of El Paso (p. 413), shows the composition of what is perhaps a typical sample of flood-plain clay. This clay is manufactured into common wire-cut brick at several plants in the valley-at Vinton and Whites Spur, above El Paso, and at others below the city. The product is of a fairly good grade, and several million bricks from this source are made yearly. Adobe bricks, made of sun-dried flood-plain clays, are manufactured extensively by the Mexican inhabitants of the Rio Grande valley and are used in the construction of their picturesque buildings.

The deposits of shale are more.important for cement making than the flood-plain clays because of their uniform texture and general freedom from coarse particles. The shale is a blue-gray clay shale of Lower Cretaceous age and occurs interbedded with sandstone and limestone on the flanks of the Cerro de Muleros. It is well exposed in the pass along the west bank of the Rio Grande and also occurs in small areas east of the river. The composition of four samples of this shale is shown by the accompanying analyses. The figures indicate a considerable variation, silica ranging from 49.08 to 75.15 per cent, alumina from 10.90 to 20.71 per cent, and lime from 0.66 to 13.56 per cent. The analyses show that the shale is well adapted for making cement, with the exception of No. 3 , which contains too much silica and relatively too much aluminum and iron for an ideal Portland cement clay. Because of the variability in composition indicated by the analyses, more tests are desirable to determine the extent of the different grades. 
Analyses of shale, clay, and limestone from the vicinity of El Paso.

[Fusion of air-dried material. Analyst, P. H. Bates, U.S. Geological Survey fuels and structural materials testing laboratory.1

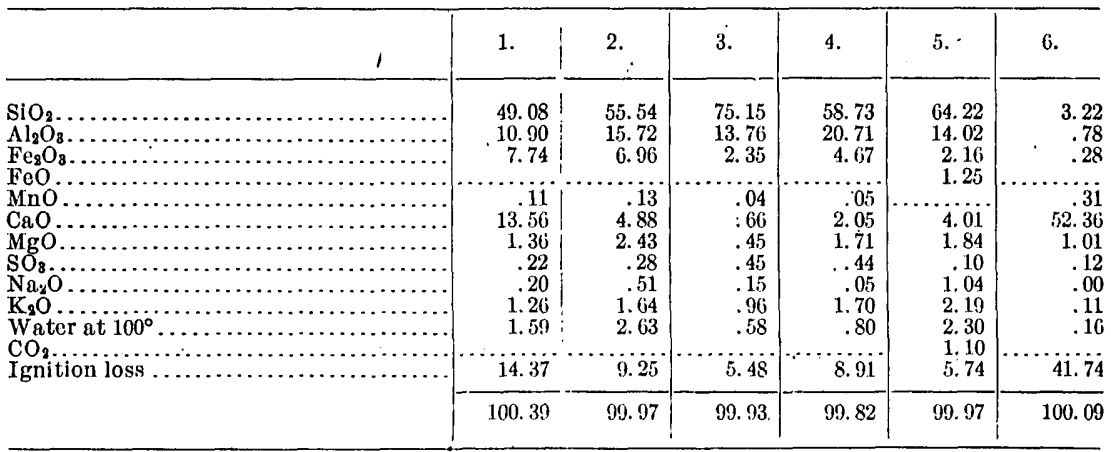

1. Shale one-fourth mile south of Courchesne quarry.

2. Shale one-fourth mile north of Courchesne quarry.

3. Shale from El Paso Brick Company's property.

4. Shale from El Paso Brick Company's property.

5. Flood-plain clay from Whites Spur, 10 miles above El Paso.

6. Limestone from Courchesne quarry.

Bricks of excellent quality are made from this shale, three grades being manufactured-pressed brick, common wire-cut brick, and fire brick. Many thousands of the first two grades are made daily, but at the present time only small quantities of fire brick are manufactured, their chief use being in the brick kilns. An analysis of fire clay is given under No. 3 in the table. It shows a small content of fluxing impurities, although the high percentage of silica, 7.5 .15 per cent, indicates only moderate refractoriness.

\section{IIMESTONE.}

The limestones of the El Paso region aggregate more than 5,000 feet in thickness and are separable into five formations, based on their ages, as follows: Lower Ordovician, Upper Ordovician, Silurian, Carboniferous, and Cretaceous. Without fossil evidence the different limestones can not always be recognized, although each has physical properties peculiar to itself. They are all massive and are in the main gray in color, but some are whitish and others are almost black. Some are more crystalline than others and they contain variable amounts of chert. A characteristic difference is their content of magnesia, as shown by the following analyses:

Lime and magnesia in limestones from the vicinity of El Paso.

\begin{tabular}{|c|c|c|c|c|c|}
\hline & $\begin{array}{l}\text { Lower } \\
\text { Ordovi- } \\
\text { cian. }\end{array}$ & $\begin{array}{l}\text { Upper } \\
\text { Ordovi- } \\
\text { cian. }\end{array}$ & Silurian. & $\begin{array}{c}\text { Carbonif- } \\
\text { erous. }\end{array}$ & $\begin{array}{l}\text { Creta- } \\
\text { ceous. }\end{array}$ \\
\hline $\begin{array}{l}\mathrm{CaO} \\
\mathrm{MgO}\end{array}$ & $\begin{array}{l}32.12 \\
16.00\end{array}$ & $\begin{array}{l}30.82 \\
18.01\end{array}$ & $\begin{array}{l}28.77 \\
18.56\end{array}$ & $\begin{array}{r}53.52 \\
.58\end{array}$ & $\begin{array}{r}52.36 \\
1.01\end{array}$ \\
\hline
\end{tabular}


The three older formations contain abundant magnesia, in quantities to constitute the rocks almost a true dolomite, but the magnesia content of the younger limestones is very small. On account of the high magnesia in the older limestones they are unfit for cement making, but those of Carboniferous and Cretaceous age are well adapted for this purpose.

The distribution of these limestones in general is distinct. The older formations outcrop along the crest and form the "backbone" of the Franklin Mountains. The Carboniferous limestone lies along the northwestern slope of this range and is particularly well developed adjacent to the Texas-New Mexico boundary line. The Cretaceous limestone outcrops along the flanks of the Cerro de Muleros and occurs also in the gorge above El Paso on both sides of the river. The greater accessibility of the Cretaceous limestone and its occurrence near the shale make it probable that this will be first used, in preference to that of Carboniferous age.

Both the magnesian and nonmagnesian limestones are burned for lime in the vicinity of El Paso. For this purpose the Ordovician limestones are quarried at the south end of the Franklin Range and the Cretaceous limestone at the pass above the city. Large quantities of the Cretaceous limestone are also quarried and crushed for use as furnace flux by the smelter in the valley 4 miles above El Paso. The rock is also extensively used for foundations and for road-making macadam. 


\section{SURVEY PUBLICATIONS ON CEMENT AND CEMENT AND CONCRETE MATERIALS.}

The following list includes the principal publications on cement materials by the United States Geological Survey, or by members of its staff. Besides the publications cited, the technologic branch of the Survey has in preparation numerous bulletins dealing with the results of tests on concrete beams and the constituent materials of concrete, etc.

Adams, G. I., and-others. Economic geology of the Iola quadrangle, Kansas. Bulletin No. 238.80 pp. 1904.

BALL, S. H. Portland cement materials in eastern Wyoming. In Bulletin No. 315, pp. 232-244. 1907.

BAssLer, R. S. Cement materials of the Valley of Virginia. In Bulletin No. 260, pp. 531-544. 1905.

Burchard, E. F. Portland cement materials near Dubuque, Iowa. In Bulletin . No. 315, pp. 225-231. 1907.

Butrs, C. Sand-lime brickmaking near Birmingham, Ala. In Bulletin No. 315, pp. 256-258. 1907.

Catrett, C. Cement resources of the Valley of Virginia. In Bulletin No. 225, pp. 457-461. 1904 .

Clapp, F. G. Limestones of southwestern Pennsylvania. Bulletin No. 249.52 pp. $\cdot 1905$.

Crider, A. F. Cement resources of northeast Mississippi. In Bulletin No. 260, pp. 510-521. 1905.

- (See also Eckel, E. C., and Crider, A. F.)

Cummings, U. American rock cement. A series of annual articles on natural cements, appearing in the volumes of the Mineral Resources U. S. previous to that for 1901 .

Duryee, E. Cement investigations in Arizona. In Bulletin No. 213, pp. 372380. 1903.

- EскEL, E. C. Slag cement in Alabama. In Mineral Resources U. S. for 1900, pp. 747-748. 1901.

1902.

The manufacture of slag cement. In Mineral Industry, vol. 10, pp. 84-95.

- The classification of the crystalline cements. In Am. Geologist, vol. 29, pp. 146-154. 1902.

- Portland cement manufacturing. In Municipal Engineering, vol. 24, pp. $335-336$; vol. 25, pp. 1-3, 75-76, 147-150, 227-230, 405-406. 1903.

- The materials and manufacture of Portland cement. In Senate Doc. No. 19, 58th Cong., 1st sess., pp. 2-11. 1.903.

- Cement-rock deposits of the Lehigh district. In Bulletin No. 225, pp. 448-450. 1904. 
ECKel, E. C. Cement materials and cement industries of the United States. Bulletin No. 243. 395 pp. 1905.

- The American cement industry. In Bulletin No. 260, pp. 496-505. 1905.

1905.

- Portland cement resources of New York. In Bulletin No. 260, pp. 522-530.

- Cement resources of the Cumberland Gap district, Tennessee-Virginia. In Bulletin 285, pp. 374-376. 1906.

- Advances in cement technology, 1906. In Mineral Resources U. S. for 1906, pp. 897-905. 1907.

__ Lime and sand-lime brick. In Mineral Resources U. S. for 1906, pp. 985-991. 1907.

Eckel, E. C., and Crider, A. F. Geology and cement resources of the Tombigbee River district, Mississippi-Alabama. Senate Doc. No. 165, 58th Cong., 3d sess. 21 pp. 1905.

Humphrey, R. L. The effects of the San Francisco earthquake and fire on various structures and structural materials. In Bulletin No. 324, pp. 14-61. 1907.

Organization, equipment, and operation of the st
laboratories at St. Louis, Mo. Bulletin No. 329. In press.

(in charge). Portland cement mortars and their constituent materials:

Results of tests, 1905 to 1907 . Bulletin No. 331 .

Kimball, L. L. Cement. A series of annual articles on the cement industry and the production of cement in the United States. In Mineral Resources U. S. for 1901, $1902,1903,1904$, and 1905.

Landes, H. Cement resources of Washington. In Bulletin No..285, pp. 377-383. 1906.

Newberry, S. B. . Portland cement. A series of annual articles on Portland cements, appearing in the various volumes of the Mineral Resources U. S. previous to that for 1901 .

Russell, I. C. The Portland cement industry in Michigan. In Twenty-second Ann. Rept., pt. 3, pp. 620-686. 1902.

Sewell, J. S. The effects of the San Francisco earthquake on buildings, engineering structures, and structural materials. In Bulletin No. 324, pp. 62-130. 1907.

Sмiтн, E. A. The Portland cement materials of central and southern Alabama. In Senate Doc. No. 19, 58th Cong., 1st sess., pp. 12-23. 1903.

- Cement resources of Alabama. In Bulletin No. 225, pp. 424-447. 1904.

TAFF, J. A. Chalk of southwestern Arkansas, with notes on its adaptability to the manufacture of hydraulic cements. In Twenty-second Ann. Rept., pt. 3, pp. 687-742. 1902. 